\title{
SHADOW ECONOMY CHANNELS AND THEIR IMPACT ON MACROECONOMIC STABILITY
}

\section{КАНАЛИ ТІНІЗАЦІЇ НАЦІОНАЛЬНОЇ ЕКОНОМІКИ ТА ЇХ ВПЛИВ НА МАКРОЕКОНОМІЧНУ СТАБІЛЬНІСТЬ}

\section{UDC 330.1}

DOI: https://doi.org/10.32843/bses.44-19

\author{
Lieonov Serhiy \\ Doctor of Economic Sciences, Professor, \\ Department of Economic Cybernetics \\ Sumy State University \\ Zolkover Andrii \\ Candidate of Economic Sciences, \\ Doctoral Student, \\ Department of Business Economics \\ and Tourism \\ Kyiv National University \\ of Technologies and Design \\ Bozhenko Victoria \\ Candidate of Economic Sciences, \\ Associate Professor, \\ Department of Economic Cybernetics \\ Sumy State University
}

\begin{abstract}
This article summarizes the arguments and counter-arguments within the scientific discussion on combating shadow activity in the context of macroeconomic stability. The study's primary purpose is to identify the main channels of illegal economic activity and analyze their impact on economic growth. The urgency of solving this scientific problem is that the shadow activity distorts the market mechanism and creates non-competitive conditions for financial entities' functioning, thereby restraining economic and social development in the country. The authors analyzed the volume of the shadow economy in Ukraine according to the methods of the Ministry of Economy and F. Schneider. The article proposes distinguishing four channels of shadowing of the economy: tax, social, investment and institutional. As a result, recommendations are proposed to prevent or minimize illegal schemes in Ukraine in terms of separate shadowing channels.

Key words: shadow economy, macroeconomic stability, taxes, corruption, informal employment, phantom investments.
\end{abstract}

Статья обобщает аргументы и контраргументы в научной дискуссии по вопросу противодействия теневой деятельности в контексте обеспечения макроэкономической стабильности. Основной челью проведенного исследования является определение основных каналов осуществления незаконной экономической деятельности и анализ их влияния на темпы экономического роста. Актуальность решения данной научной проблемы заключается в том, что теневая деятельность деформирует рыночный механизм и создает неконкурентные условия для ффункционирования субъектов хозяйствования, тем самым сдерживая экономическое и социальное развитие в стране. Авторами проанализированы объем теневой экономики в Украине по методике Минэкономики и Ф. Шнайдера. В статье предложен выделять четыре канала тенизации экономики: налоговый, социальный, инвестиционный и институциональный. В итоге предложены рекомендации по недопущению или минимизации использования нелегальных схем в Украине в разрезе выделенных каналов тенизации.

Ключевые слова: теневая экономика макроэкономическая стабильность, налоги, коррупция, неформальная занятость, фриктивные инвестиции.

Актуальність вирішення наукової проблеми щодо необхідності ідентифрікації впливу деструктивних процесів через різні канали детінізації національної економки, полягає в тому, що тіньова діяльність спотворює ринковий механізм і створює неконкурентні умови для фрункціонування фрінансових суб'єктів, тим самим стримуючи економічний та соціальний розвиток країни. Основна мета дослідження - ідентифрікувати основні канали нелегальної економічної діяльності та проаналізувати їх вплив на економічне зростання. На основі комплексного поєднання бібліографрічного, економетричного та статистичного методів у роботі фрормалізовано чотири канали тінізації економіки: податковий, соціальний, інвестиційний та інституційний. Автори проаналізували обсяги тіньової економіки в Україні за методами Міністерства розвитку економіки, торгівлі та сільського господарства та Ф. Шнайдера. Емпірично доведено, що надмірне податкове навантаження на бізнес та громадян, складність системи адміністрування податків та обов'язкових платежів, отримання незаконного відшкодування Пдв та функціонування конвертаційних центрів призводять до зростання тіньової економіки. Прямі та порторельні інвестиції, що надходять з офршорних юрисдикцій або спрямовуються на них, шкідливо впливають на макроекономічну та фрінансову стабільність країни. Високі ставки оподаткування доходів срізичних осіб, відсутність есрективного контролю за реєстрацією працівників на підприємствах та прийнятне ставлення громадян до неформальної зайнятості та виплати заробітної плати «в конвертах» призвели до активного розвитку незадекларованої праці в Україні. В результаті пропонуються рекомендації щодо запобігання або мінімізації незаконних схем в Україні з точки зору окремих каналів тінізації. Результати дослідження можуть бути корисними для органів виконавчої влади при фрормуванні державної інвестиційної політики, спрямованої на поліпшення якості ділового середовища, зменшення адміністративного тягаря та посилення інвестиційного попиту з боку іноземних інвесторів з метою інтенсифікації процесів детінізації національної економіки.

Ключові слова: тіньова економіка, макроекономічна стабільність, податки, корупція, неформальна зайнятість, оріктивні інвестиції.

Introduction. Ensuring macroeconomic stability in the country is a crucial task of public authorities at various levels, which allows maintaining the country's economic growth, forming a margin of financial strength to avoid significant recessions during the worsening of the crisis. One of the critical factors of the destructive impact on macroeconomic stability is the informal sector of the economy. Shadow economic relations create non-competitive conditions for business entities and narrow the opportunities for the expanded reproduction of officially operating enterprises, thereby restraining the state's potential economic growth, and improving the welfare of its citizens.

Problem statement. The question of the impact of shadow economic activity on the country's economic growth belongs to the sphere of scientific interests of many scientists. The study of the preconditions, consequences and approaches to assessing the scale of the shadow economy is one of the critical issues of scientific work of domestic and foreign scientists, namely Boiko A.O. [5], Levchenko V.P. [7], Samusevych Ya.V. [3; 5], Vysochyna A.V. [3], Tiutiunyk I.V. [3], Dubrovskyi V. [1; 2], Nguedie J. [9], Marriage Z. [8]. The issue of the impact of foreign investment on the rate of economic growth in the country belongs to the sphere of scientific interests of many scientists, among which are D. Bovmik [6].

Numerous studies by F. Schneider $[10 ; 11 ; 12]$ show that the interaction between the official and the shadow economy occurs. Still, the dominance of positive effects over negative ones or vice versa is debatable. According to F. Schneider, these effects depend 
on the size of the shadow economy, the intensity of interaction between the formal and informal sectors of the economy, the state of socio-economic development in the country and so on. In the work of S. Williams [14], it was emphasized that the shadow economy has a positive effect on economic growth, which is explained, firstly, by the improvement of the competitive environment through the involvement of more economic entities (including illegal), and - second, the ability of businesses operating in the shadows to avoid strict government regulations in the informal sector, but at the same time create added value and jobs.

However, despite the extensive coverage in the scientific literature of the problems of counteracting shadow financial operations, the question of the actual and potential channels of shadowing of the economy needs additional substantiation.

The purpose of the research is to identify and analyze the main channels of illegal economic activity in Ukraine.

Results of the research. Today, the main determinants of the use of shadow transactions in the activities of economic entities are high tax pressure on business, excessive regulation of economic activity, which creates difficulties in doing business, corruption among government officials, low level of control and supervision of economic processes, rapid development of information technology, which leads to the emergence of digital currencies, e-wallets, etc., increased payments on the Internet and the lack of a clear mechanism for regulating these transactions.

Despite the adoption of numerous legislative initiatives to combat illegal financial and economic transactions, in Ukraine, a third of monetary transactions are still in the shadows (Figure 1). According to the Ministry of Economic of Ukraine estimates in 2018, the volume of the shadow economy amounted to $30 \%$ of GDP, which is $11 \%$ and $16.7 \%$ less than in 2017 and 2010. The data in Figure 1 clearly show that the data on the level of shadowing of the economy according to the Ministry of Economic Development method of Ukraine is slightly lower compared to the results of F. Schneider (on average by $16.9 \%$ or 5.7 percentage points).

When studying the channels of shadowing of the economy, it is advisable to consider the relations that arise between economic entities in the process of primary and secondary distribution and redistribution of GDP (in the production of goods and sales, wages, taxes and mandatory payments to budgets of different levels, conducting financial transactions, allocating funds from state funds, etc.).

Considering the variety of tools and methods of illegal activity, it is proposed to identify four channels of shadowing of the economy, which have a potential direct or indirect impact on macroeconomic stability in the country:

1. Tax channel.

One of the critical factors leading to an increase in the country's shadow sector is the excessive tax burden on businesses and citizens, the complexity of the system of administration of taxes and mandatory payments, obtaining illegal VAT refunds, and the operation of conversion centers and more. It is established that increasing the level of taxation by 1 point (on a scale from 1 to 5 , according to the method of determining the index of tax freedom) leads to a decrease in the economy's shadowing by $9 \%$ [13]. Lack of tax revenues or misuse of budget funds leads to structural distortions in developing the national economy and reduced economic well-being.

2. Investment channel.

Due to the excessive tax burden on business and their over-regulation and the lack of adequate reforms to restructure its economy, national financial resources are regularly exported in foreign direct and portfolio investment, thereby harming the country's macroeconomic and financial stability.

Every year, national regulators and international organizations make decisions aimed at strengthening the control and supervision of financial transactions through companies from offshore jurisdictions that disregard generally accepted global standards of corporate and financial transparency and promote the

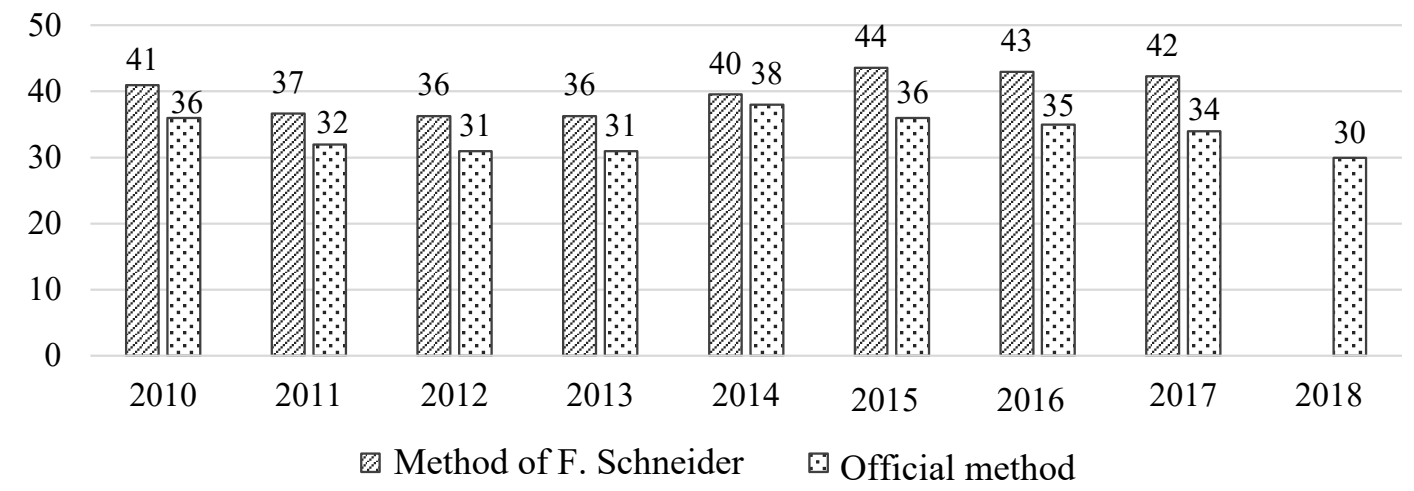

Figure 1. The dynamics of the level of the shadow economy in Ukraine in 2010-2018, \% of GDP 
legalization of illicit funds, slowing down the pace of development - also increasing the uneven distribution of income. In 2017, Ukraine adopted a legal act that establishes additional control and supervision by the relevant executive bodies when making payments to non-residents of individual countries. Thus, in 2019, Ukraine invested indirect investments in these countries' economy in the amount of 1.466 billion US dollars. That is, about $41.4 \%$ of the total foreign direct investment may be fictitious. According to the International Consortium of Investigative Journalists (ICIJ), which specializes in disclosing information about residents of countries (both citizens and companies) who use offshore areas to conceal illicit income, minimize or avoid taxation. Direct and portfolio investments coming from or directed to offshore jurisdictions will generally not be used for their intended purpose. Thus, these figures show that domestic legal entities and individuals use the services of companies from offshore jurisdictions to a greater extent than in European countries.

3. Institutional channel.

Given the central role of the executive and legislature in preventing the spread of shadow processes in the economy and stimulating long-term economic growth, the state of the country's institutional environment is essential in counteracting the spread of illegal transactions. Adherence to the rule of law, trust in the government and the absence of corrupt practices in the judiciary are critical priorities. They form the basis for creating effective institutions to combat the shadowing of the economy.

4. Social channel.

High rates of personal income taxation, lack of effective control over the registration of employees in enterprises, as well as in most cases, the acceptable attitude of citizens to informal employment and payment of wages "in envelopes" led to the active development of undeclared work in Ukraine.

Conclusions and prospects of further research. Summing up, we present the main recommendations for preventing or minimizing the use of illegal schemes in Ukraine in the context of ensuring its macroeconomic stability. Tax channel: to improve the work of employees of the tax and customs services in terms of impartial and professional inspections; modernize interdepartmental relations by combining the efforts of representatives of the financial sector, as well as regulators and supervisors; to strengthen international cooperation on preventing the participation of economic entities in the country in transnational tax avoidance schemes; to improve the system of tax administration; strengthen liability for tax evasion, including the introduction of criminal liability for concealment of income or disregard of the object of taxation, if these actions caused damage to the state in large or substantial amounts; introduce innovative approaches for monitoring suspicious financial trans- actions using the capabilities of artificial intelligence and machine learning, etc. Institutional channel: to continue the policy of intensive implementation of e-government at the state and local levels; reduce the level of bureaucratization in the public administration system, increase the efficiency of the judiciary and ensure equal access to fair justice, and more. Investment channel: to provide the disclosure of information on persons who use offshore jurisdictions to conceal income or avoid taxation, as well as to establish increased financial responsibility for them; to continually adjust the financial monitoring system considering the growing threats and improved methods of money laundering. Social channel: to increase the level of financial literacy of the population by intensifying lifelong learning programs; reduce the degree of asymmetry between state and public tax morality, etc. In conclusion, to reduce the shadow economy scale or slow down its spread, it is not enough to use direct control to identify and punish the shadow economy. Still, it is essential to cultivate respect for civil society institutions and unquestioning compliance with legal and physical persons.

\section{REFERENCES:}

1. Dubrovskyi, V., Cherkashyn, V. (2017). Porivnialnyi analiz fiskalnoho efektu vid zastosuvannia instrumentiv ukhylennia/unyknennia opodatkuvannia v Ukraini [Comparative analysis of the fiscal impact of tax avoidance in Ukraine]. Kyiv. Retrieved from: https://rpr.org.ua/ wp-content/uploads/2018/02/Instrumenty-uhylyannyavid-splatypodatkiv-2017-1.pdf

2. Dubrovskyi, V., Cherkashyn, V., Hetman, O. (2017). Yak zmenshyty mozhlyvosti dlia ukhylennia vid splaty podatkiv pry importi ta prodazhi tovariv, zokrema cherez zlovzhyvannia sproshchenoiu systemoiu opodatkuvannia? [How to reduce the potential for tax evasion when importing and selling goods, through the abuse of a simplified tax system]. Retrieved from: https://rpr.org.ua/ wp-content/uploads/2017/04/Yak-zmenshyty-mozhlyvosti-dlya-uhylennya-vid-splaty-podatkiv-pry-importi-taprodazhi-tovariv-zokrema-cherez-zlovzhyvannya-sproschenoyu-systemoyu-opodatkuvannya.pdf

3. Samusevych, Ya. V., Vysochyna, A. V. (2018). Zarubizhni praktyky otsiniuvannia obsiahiv vyvedennia kapitalu: metodolohichnyi aspekt [Foreign practices of estimating the volume of capital withdrawal: methodological aspect]. Scientific Bulletin of Uzhgorod National University, 21, 81-85.

4. Tiutiunyk, I. V., Kobushko, Ya. V. (2018). Instrumenty minimizatsii podatkovoho navantazhennia ekonomichnymy subiektamy v Ukraini: porivnialnyi analiz ta efekty vid zastosuvannia [Instruments of tax burden minimization by economic entities in Ukraine: comparative analysis and effects from application]. Economic analysis, 28(4), 122-130.

5. Boiko, A., Samusevych, I. (2017). The role of tax competition between the countries of the world and the features of determining the main tax competitors of Ukraine among the European countries. Financial Mar- 
kets, Institutions and Risks, 1(1), 72-79. Retrieved from: http://doi.org/10.21272/fmir.1(1).72-79.2017

6. Bhowmik, D. (2018). Financial Crises and Nexus Between Economic Growth and Foreign Direct Investment. Financial Markets, Institutions and Risks, 2(1), 58-74. Retrieved from: http://doi.org/10.21272/ fmir.2(1).58-74.2018

7. Levchenko, V., Kobzieva, T., Boiko, A., Shlapko, T. (2018). Innovations in Assessing the Efficiency of the Instruments for the National Economy De-Shadowing: the State Management Aspect. Marketing and Management of Innovations, 4, 361-371. Retrieved from: http://doi.org/10.21272/mmi.2018.4-31

8. Marriage, Z. (2018). The elephant in the room: offshore companies, liberalisation and extension of presidential power in DR Congo. Third World Quarterly, 39(5), 889-905. Retrieved from: https://doi.org/10.1080/ 01436597.2018 .1447373

9. Nguedie, Y. H. N. (2018). Corruption, Investment and Economic Growth in Developing Countries: A Panel Smooth Transition Regression Approach. SocioEconomic Challenges, 2(1), 63-68. Retrieved from: https://doi.org10.21272/sec.2(1).63-68.2018

10.Schneider, F. (2006). Shadow Economies and Corruption of 145 Countries All Over the World: What Do We Really Know? IZA Discussion Paper, no. 2315.

11. Schneider, F. (2005). Shadow Economies Around the World: What Do We Really Know? European Journal of Political Economy, 21(3), 598-642.

12. Schneider, F., Hametner, B. (2007). The Shadow Economy in Columbia: Size and Effects on Economic Growth. Peace Economics, Peace Science and Public Policy, 20(2), 293-325.

13. Singh, A., Jain-Chandra, S., Mohommad, A. (2012). Inclusive Growth, Institutions, and the Underground Economy. IMF Working paper. Retrieved from: https://www.imf.org/external/pubs/ft/wp/2012/wp1247.pdf

14. Williams, C. C. (2006). The Hidden Enterprise Culture: Entrepreneurship in the Underground Economy. Cheltenham: Edward Elgar Publishing.

\section{БІБЛІОГРАФІЧНИЙ СПИСОК:}

1. Дубровський В., Черкашин В. Порівняльний аналіз фріскального ефекту від застосування інструментів ухилення/уникнення оподаткування в Україні. Інститут соціально-економічної трансфрормації. Київ, 2017. 36 с. URL: https://rpr.org.ua/ wp-content/uploads/2018/02/Instrumenty-uhylyannyavid-splatypodatkiv-2017-1.pdf

2. Дубровський В., Черкашин В., Гетман О. Як зменшити можливості для ухилення від сплати податків при імпорті та продажі товарів, зокрема через зловживання спрощеною системою оподатку- вання? Інститут соціально-економічної трансформації. Київ, 2017. 36 с. URL: https://rpr.org.ua/wp-content/ uploads/2017/04/Yak-zmenshyty-mozhlyvosti-dlyauhylennya-vid-splaty-podatkiv-pry-importi-ta-prodazhitovariv-zokrema-cherez-zlovzhyvannya-sproschenoyusystemoyu-opodatkuvannya.pdf

3. Самусевич Я. В., Височина А. В. Зарубіжні практики оцінювання обсягів виведення капіталу: методологічний аспект. Науковий вісник Ужгородського національного університету. 2018. Випуск 21. Частина 2. С. 81-85.

4. Тютюник І.В., Кобушко Я.В. Інструменти мінімізації податкового навантаження економічними суб'єктами в Україні: порівняльний аналіз та ефекти від застосування. Економічний аналіз. 2018. Том 28. № 4. C. 122-130.

5. Boiko A., Samusevych I. The role of tax competition between the countries of the world and the features of determining the main tax competitors of Ukraine among the European countries. Financial Markets, Institutions and Risks. 2017. № 1(1). C. 72-79.

6. Bhowmik D. Financial Crises and Nexus Between Economic Growth and Foreign Direct Investment. Financial Markets, Institutions and Risks. 2018. № 2(1). P. 58-74.

7. Levchenko V., Kobzieva T., Boiko A., Shlapko T. Innovations in Assessing the Efficiency of the Instruments for the National Economy De-Shadowing: the State Management Aspect. Marketing and Management of Innovations. 2018. № 4. P. 361-371.

8. Marriage Z. The elephant in the room: offshore companies, liberalisation and extension of presidential power in DR Congo. Third World Quarterly. 2018. № 39(5). P. 889-905.

9. Nguedie Y. H. N. Corruption, Investment and Economic Growth in Developing Countries: A Panel Smooth Transition Regression Approach. SocioEconomic Challenges. 2018. № 2(1). P. 63-68.

10. Schneider F. Shadow Economies and Corruption of 145 Countries All Over the World: What Do We Really Know? IZA Discussion Paper. 2006. No. 2315.

11.Schneider F. Shadow Economies Around the World: What Do We Really Know? European Journal of Political Economy. 2005. 21(3). P. 598-642.

12. Schneider F., Hametner B. The Shadow Economy in Columbia: Size and Effects on Economic Growth. Peace Economics, Peace Science and Public Policy. 2007. 20(2). P. 293-325.

13. Singh A., Jain-Chandra S., Mohommad A. Inclusive Growth, Institutions, and the Underground Economy. IMF Working paper. 2012. URL: https://www.imf.org/external/ pubs/ft/wp/2012/wp1247.pdf

14. Williams C.C. The Hidden Enterprise Culture: Entrepreneurship in the Underground Economy. 2006. Cheltenham: Edward Elgar Publishing. 